\title{
Contextual Effect of Integrated Heath Post on Nutritional Status among Children Aged 6-59 Months in Surabaya, East Java
}

\author{
Triana Ulfa Nur Aziza1), Yulia Lanti Retno Dewi²), \\ Eti Poncorini Pamungkasari2) \\ ${ }^{1)}$ Masters Program in Public Health, Universitas Sebelas Maret \\ 2)Faculty of Medicine, Universitas Sebelas Maret
}

\section{ABSTRACT}

Background: A child will come into toddler phase which is the rapid growth and development phase. It turns children into one of the groups that vulnerable to suffer from under nutrition. The data of Riskesdas (Basic Health Research) in 2018 indicates that the percentage of malnutrition and under nutrition in Indonesia is $17.7 \%$, in which the number is still higher than the target of National Medium Term Development Plan 2019 which is $17 \%$. The study aimed to analyzes factors that affect nutritional status of children aged 6 59 months in Surabaya, East Java.

Subjects and Method: This was a cross sectional study conducted at 25 integrated health posts (posyandu) in Surabaya, East Java, from August to September 2019. A sample of 200 children aged 6-59 months was selected by stratified random sampling. The dependent variable was nutritional status (weight for age). The independent variables were history of exclusive breastfeeding, history of low birth weight (LBW), maternal educational level, maternal knowledge, maternal occupation, family income, and environmental hygiene and sanitation. The data were collected by questionnaire and analyzed by a multiple logistic regression run on Stata 13.
Results: Poor nutritional status increased with the history of LBW $(b=5.29 ; 95 \% \mathrm{CI}=1.87$ to $6.72 ; \mathrm{p}=0.003$ ) and poor environmental hygiene and sanitation $(b=3.35 ; 95 \% \mathrm{CI}=0.77$ to $5.94 ; \mathrm{p}=$ o.011). Poor nutritional status decreased with maternal educational status $\geq$ Senior high school $(b=-2.81 ; 95 \% \mathrm{CI}=-5.24$ to $-0.38 ; \mathrm{p}=0.023)$, high maternal knowledge $(\mathrm{b}=-2.68 ; 95 \% \mathrm{CI}=-$ 5.01 to $-0.35 ; \mathrm{p}=0.024)$, and high family income $(b=-3.37 ; 95 \% \mathrm{CI}=-6.04$ to $-0.71 ; \mathrm{p}=0.013)$.

Conclusion: Poor nutritional status increases with the history of LBW and poor environmental hygiene and sanitation. Poor nutritional status decreases with maternal educational status $\geq$ senior high school, high maternal knowledge, and high family income.

Keywords: nutritional status, birth weight, sanitation, children under five

\section{Correspondence:}

Triana Ulfa Nur Aziza. Masters Program in Public Health, Universitas Sebelas Maret, Jl. Ir.Sutami 36A, Surakarta, Central Java, Indonesia. Email: trianaulfanuraziza@gmail.com. Mobile: +6281358396565

Cite this as:

Aziza TUN, Dewi YLR, Pamungkasari EP (2020). Contextual Effect of Integrated Heath Post on Nutritional Status among Children Aged 6-59 Months in Surabaya, East Java. J Matern Child Health. 5 (1): 78-86. https://doi.org/10.26911/thejmch.2020.05.01.09

c) (7) (-) Journal of Maternal and Child Health is licensed under a Creative Commons Attribution-Non Commercial-Share Alike 4.o International License.

\section{BACKGROUND}

Mothers and children in the family component are the most vulnerable groups. It is related with pregnancy, childbirth and puerperium phase on mothers and growth and development phase on children (Riyadi, 2016).
Children will come into toddler phase which is a rapid growth and development phase and become one of groups that is vulnerable to suffer from under nutrition in a community group (Istiany A, 2013).

Under nutrition among children under five leads to very harmful impacts namely 
educed immune system so that they are easily getting infectious diseases, reduced body endurance, reduced IQ, low cognitive competence and it even leads to death. Nutritional issues especially among children under five are affected by a lot of factors, both internal and external factors. Some internal factors that may affect the nutritional status of children under five are food digestibility score, health status, condition of infection, age, history of complementary food, and others. Whereas the external factors among others are amount of family income, level of maternal education, level of maternal knowledge, whether working mothers or not, number of family members and others (Adriani, 2016).

\section{SUBJECTS AND METHOD}

\section{Study Design}

This was an analytic observational study with a cross sectional design. The study was conducted at 25 integrated health posts, in Krembangan and Pabean Cantika sub-districts, Surabaya, East Java, from August to September 2019.

\section{Population and Sample}

Population in the study was mothers whose babies aged $6-59$ months who dispersedly live around 25 Posyandu. A sample of 200 children aged 6-59 months was selected for this study by stratified random sampling.

\section{Study Variables}

The dependent variable was nutritional status (weight for age). The independent variables were maternal education, maternal knowledge, maternal occupation, family income, LBW, exclusive breastfeeding, and environmental hygiene and sanitation.

\section{Operational Definition of Variables} Maternal education based on mothers' highest level of formal education when the study was conducted. The data were collected by questionnaire. The measurement scale was categorical.
Maternal occupation was maternal activities who worked outside the house to earn income excluding their regular household chores. The data were collected by questionnaire. The measurement scale was categorical.

Maternal knowledge was measured by recognizing the level of maternal knowledge about the fulfillment of balanced nutrition for children under five and nutritional status of children under five. The data were collected by questionnaire. The measurement scale was continuous and transformed into dichotomous.

Family income was measured by calculating the total income obtained by a family, in form of average income in the last 6 months. The data were collected by questionnaire. The measurement scale was continuous and transformed into dichotomous.

History of LBW was a history of a baby born weighed less than 2,500 grams. The data were collected by questionnaire. The measurement scale was continuous and transformed into dichotomous.

Exclusive breastfeeding was a history of breastfeeding in exclusive manner which is giving a baby aged $\mathrm{o}-6$ months only breast milk without any complement. The instrument was questionnaires. The data scale used was continuous and was modified into dichotomy to facilitate data analysis.

Environmental hygiene and sanitation understood the effort of disease prevention that emphasize on the effort of environmental health and healthy and clean behavior. Continuous and transformed into dichotomous.

Nutritional Status was measured by anthropometry based on weight for age. Data collection was conducted by using weight scale and growth chart. The measurement scale continuous and transformed into dichotomous. 


\section{Data Analysis}

Sample characteristics in continuous data were described in mean, minimum, and maximum. Sample characteristics in continuous data were described in frequency (n) and percent (\%). Bivariate analysis was performed by Chi-square. Multivariate analysis was performed by multilevel multiple logistic regression.

\section{Research Ethic}

The study was conducted based on research ethics, namely informed consent, anonymity, confidentiality, and research ethics. The research ethics was obtained from Dr. Moe- wardi Hospital, Surakarta, Central Java, with No.941/-VII/HREC/2019.

\section{RESULTS}

\section{Sample Characteristics}

Sample characteristics in continuous data was presented in Table 1 .

\section{Univariate analysis}

Table 2 indicates that $67 \%$ mothers had education $\geq$ Senior high school, $76 \%$ mother were unemployed, and 60\% had good knowledge. As many as $87.0 \%$ children had normal birth weight and $84 \%$ had normal nutritional status (weight for age).

Table 1. Sample characteristics (continuous data)

\begin{tabular}{lccccc}
\hline Variables & n & Mean & SD & Minimum & Maximum \\
\hline Income (in million rupiah) & 200 & 3.94 & 2.99 & 1.5 & 20 \\
Maternal knowledge & 200 & 34.30 & 6.05 & 8 & 40 \\
Environmental Hygiene & 200 & 53.02 & 6.58 & 20 & 60 \\
\hline
\end{tabular}

Table 2. Sample characteristics (categorical data)

\begin{tabular}{lcc}
\hline Variable & Frequency (n) & Percentage (\%) \\
\hline Maternal Education & 66 & \\
<Senior high school & 134 & 33.0 \\
zSenior high school & & 67.0 \\
Maternal Occupation & 152 & 76.0 \\
$\begin{array}{l}\text { Homemaker/work at home } \\
\text { Work outside }\end{array}$ Maternal knowledge & 48 & 24.0 \\
Insufficient & 80 & 40.0 \\
Sufficient & 120 & 60.0 \\
Income & & \\
Low & 92 & 46.0 \\
High & 108 & 54.0 \\
History LBW & & \\
Normal birth weight & 174 & 87.0 \\
Low birth weight & 26 & 13.0 \\
Exclusive breastfeeding & & \\
Yes & 100 & 50.0 \\
No & 100 & 50.0 \\
Hygiene and sanitation & & \\
Good & 107 & 53.5 \\
Poor & 93 & 46.5 \\
Nutritional Status & & \\
Normal & 168 & 84.0 \\
Under nutrition & 32 & 16.0 \\
\hline
\end{tabular}




\section{The result of multilevel multiple logistic regression}

Multivariate analysis used multilevel multiple logistic regression and analyzed by using Stata 13. Multivariate analysis examined the effect of more than 1 independent variables toward 1 dependent variable. Table 3 indicated that maternal education, maternal knowledge, maternal occupation, family income, history of LBW, exclusive breastfeeding, and environmental hygiene and sanitation were associated with nutritional status (weight for age).

LBW $(b=5.29 ; 95 \% \mathrm{CI}=1.87$ to $6.72 ; \mathrm{p}=$ o.003) and poor environmental hygiene and sanitation $(b=3.35 ; 95 \% \mathrm{CI}=0.77$ to $5.94 ; \mathrm{p}=$ o.011) increased the risk of underweight in aged 6-59 months.

Maternal education $\geq$ Senior high school $(b=-2.81 ; 95 \% \mathrm{CI}=-5.24$ to $-0.38 ; \mathrm{p}=0.023)$, employed mothers $(b=-1.09 ; 95 \% \mathrm{CI}=-3.88$ to $1.69 ; \mathrm{p}=0.443$ ), good maternal knowledge $(b=-2.68 ; 95 \% \mathrm{CI}=-5.01$ to $-0.35 ; \mathrm{p}=0.024)$, high family income $(\mathrm{b}=-3.37 ; 95 \% \mathrm{CI}=-6.04$ to $-0.71 ; \mathrm{p}=0.013$ ), and non-exclusive breastfeeding $(b=-1.53 ; 95 \% \mathrm{CI}=-3.99$ to $0.92 ; \mathrm{p}=$ o.220) decreased the risk of underweight in aged 6-59 months. Posyandu had contextual effect on child nutritional status (weight for age) with intra-class correlation (ICC)= $17.58 \%$.

Table 3. Multilevel multiple logistic regression analysis about factors that affect nutritional status of children under five

\begin{tabular}{lcccc}
\hline \multicolumn{1}{c}{ Variable } & b & \multicolumn{2}{c}{ (95\%) CI } & p \\
Fixed Effect & & $\begin{array}{c}\text { Lower } \\
\text { Limit }\end{array}$ & $\begin{array}{c}\text { Upper } \\
\text { Limit }\end{array}$ & p \\
Maternal education ( $\geq$ Senior high school) & -2.81 & -5.24 & -0.38 & 0.023 \\
Unemployed mother & -1.09 & -3.88 & 1.69 & 0.443 \\
Maternal knowledge (good) & -2.68 & -5.01 & -0.35 & 0.024 \\
Family income ( $\geq$ Rp 3,800,000) & -3.37 & -6.04 & -0.71 & 0.013 \\
Low birth weight & 5.29 & 1.87 & 6.72 & 0.003 \\
Exclusive breastfeeding (no) & -1.53 & -3.99 & 0.92 & 0.220 \\
Hygiene and sanitation (poor) & 3.35 & 0.77 & 5.94 & 0.011 \\
Random Effect & & & & \\
Strata posyandu Var (Constanta) & 0.25 & 0.02 & 6.53 & \\
ICC & $17.58 \%$ & & & \\
LR test vs. Linear regression & 0.168 & & & \\
\hline
\end{tabular}

\section{The effect of maternal educational on nutritional status (weight for age)}

Level of education closely related with one's level of intelligence in adapting with her environment (Vollmer et al., 2017).

Education of a mother gives positive effect on the quality of care given to her children, since women is the holder of main duty in children health care. Mother with high education may use health facilities more effectively and interact well with health workers (Dessie et al., 2019; Corsi et al., 2016).
Education also affects children's growth and development since highly educated mothers give more stimulus to their children so that positively affects gross motor development of children under 2 years old (Kusuma et al., 2017).

Highly educated mothers can communicate better with their children therefore mother understand what their children need and desire. As the result highly educated mothers are more able to cope with children's appetite (Osguei et al., 2019; Makoka et al., 2015). 


\section{The effect of maternal occupation on nutritional status (weight for age)}

Eshete et al. (2017) in her study conveys that the status as working mothers does not turn into significant factor toward nutritional status of children under five since even though mothers work outside the house, while mothers are working the care and nurture of their children are substituted by nanny (caregiver). While mothers are working, they still can ensure children's' safety and development so that children still feel that they are given attention and mothers will not miss to recognize child growth and development.

Working mothers have better control toward food related with the increasing accessibility and affordability toward various types of foods (Renzaho et al., 2018).

In addition to accessibility toward food, working mothers also have wider knowledge about health and good nutrients for children and are able to directly implement it to children. It is related with maternal communication frequency with other people. Working mothers are more communicative and easier to receive information from outside, and more able to filter good information from the less one for their children's health (Alderman and Headey, 2017; Miller et al., 2017).

\section{The effect of maternal knowledge on nutritional status (weight for age)}

Dessie et al. (2019) reveals that the level of maternal knowledge is directly proportional with the level of maternal education. If the level of maternal education is low, the maternal knowledge turns to be less excellent since mothers without formal education experience or ones with low educational level have limited knowledge and information access especially in this term are nutritional fulfillment, providing good food intake, and also the limited knowledge about parenting style.

Maternal ability to process received information, the method to filter good information from the less one, obtaining skills, and good parenting behavior toward their children, are all affected by the level of maternal knowledge. Well educated and knowledgeable women will not doubt and be afraid to use healthcare facilities, interact and communicate more effectively with professional health workers in accordance with children's health condition. In addition, well-educated and knowledge able mothers also tends to be able to maintain the cleanliness of the environment (Pal et al., 2017).

\section{The effect of family income on nutri- tional Status (weight for age)}

High amount of income in a family usually affects the amount and varieties of menu in the household. The higher the income of a family, the more able the family to consume various varieties of food so that the food in the household has high variety (Mutisya et al., 2015).

Variety in the menu is proven to be closely related with children's nutritional status, especially toddler phase in which it is the phase to identify different kinds of food. If children are accustomed to consume a great deal of kinds of food, their nutrient needs will tend to be fulfilled compared to children who are constantly given only certain variety of food.

Furthermore, children who are given different varieties of food since early age will be familiar and recognize which food to be more desired and increase appetite. In addition to have more varied diet, families with high economy are likely to have more access to health care service, and better environmental condition (Mahmudiono et al., 2018).

\section{The effect of history of low birth weight on nutritional status (weight for age)}

Low birth weight is one of the most important variables that affect the nutritional status of children aged o - 59 months. Low birth weight leads to the increased risk of morbi- 
dity and mortality on children as the result of under nutrition (Khaing et al., 2019).

Low birth weight increases the risk of under nutritional status on children because of increased vulnerability of children with LBW toward infectious diseases such as diarrhea, respiratory tract infection and the increased risk of complication such as jaundice, anemia, chronic lung disorder, and more vulnerable to suffer from decreased appetite compared to children with normal birth weight. Higher morbidity is indicated in groups of toddlers with history of LBW (Khanal et al., 2014). LBW also increase the risk of mortality by 20 times compared to infants with normal birth weight (Rahayu et al., 2018).

\section{The effect of history of exclusive breastfeeding on nutritional status (weight for age)}

The result of the study indicated that children without the history of exclusive breastfeeding have lower log odd to be undernourished compared to toddlers with history of exclusive breastfeeding. It is caused by the range of toddlers' age in the study was quite wide that was between 6 up to 59 months, it means there are a lot of causal factors that may happen during the age range that lead toddlers with history of exclusive breastfeeding during $0-6$ month are still at risk for suffering from under nutrition. Those factors may be because toddlers who are exclusively breastfed up to 6 months old, are keep on breastfed with delayed initiation of complementary food.

Delayed initiation of complementary food may 5 times increase the risk of under nutrition (Rose et al., 2016). Another factor is that within the range of $6-59$ months of age there is a period when toddlers are at high risk for suffering from diarrhea and the diarrhea incident affects toddlers' weight. The high incident rate of diarrhea is related with baby's age that is between the ranges of
6 -12 months of age, in which within the range of age those babies have started to get complementary food in addition to breast milk. These children start to actively move so that it increase the risk to make contact with bacteria and germs (Tamimi et al., 2016).

Another causal factor is because of several reasons usually children who are not breastfed exclusively will be bottle-fed by using formula milk. Breastfeed and formula milk is the main source of protein during childhood. Babies who are fed with formula milk are estimated obtain $66-70 \%$ more protein (gram per kilogram of body weight) compared to breastfed babies within the first 6 months of their life. It results in babies who are fed with formula milk having more weight compared to exclusively breastfed babies therefore it affects the nutritional status of toddlers especially weight for age (Wright et al., 2016).

\section{The effect of hygiene and sanitation on nutritional status (weight for age)}

Toddlers who live in environment with poor hygiene and sanitation will often undergo morbidity and infection incidents. The most frequent infection among children who live in environment with poor clean water access, sanitation and hygiene are diarrhea and parasite infection.

The frequent exposure to diarrhea and parasite infection will lead to Environmental Enteropathy (EE). EE is the inflammation condition inside children's intestines marked by atrophy on Villi, hyperplasia, increased permeability, cell inflammation, and malabsorption. The incidents of diarrhea and EE among children are the connecting factors between poor environmental hygiene and sanitation with under nutritional status. Diarrhea and parasitic worms lead to nutrition loss and the nutrition intake will be diverted instead of for the growth and development, the nutrition is diverted to 
immune system to fight the infection (Crane et al., 2015; Rah et al., 2015).

Children who live in environment with clean water access, good sanitation and live in a family that is familiar with washing hands undergo better development such as reduced risk of infection incidents, reduced risk of inflammation, and increased social interaction, and increased synaptic connection and myelin sheaths in central nerve system, that may give good impact to children development (Tofail et al., 2018; Rose et al., 2016).

\section{The effect of integrated health post on nutritional status (weight for age)}

Maternal satisfactory toward healthcare facilities greatly depends on the service quality, infrastructures, mileage from home, cleanliness and aesthetics of healthcare facilities (Creanga et al., 2017). Mothers who feel satisfied will show positive toward the benefits of Posyandu's activities. The main reason of mothers to come to posyandu especially for mothers with positive attitude is to monitor children's weight and nutritional status that their children's growth can always be optimal (Nazri et al., 2016).

One of the efforts to improve the quality of healthcare service is by improving access and community participation toward the facility so that community can also receive the benefit of the healthcare facility and improving their health status (Rahayu et al., 2019). It is because Posyandu is the healthcare facility used to identify and conduct early detection toward the growth and development of children under five (Pangestu et al., 2017).

\section{AUTHOR CONTRIBUTION}

Triana Ulfa Nur Aziza conducted the study, collected data, formulated the article, and processed the data. Yulia Lanti Retno Dewi contributed in formulating thinking frame- work of the study. Eti Poncorini Pamungkas contributed in the formulation of method of the study as well as the discussion of the study.

\section{CONFLICT OF INTEREST}

There was no conflict of interest in this study.

FUNDING AND SPONSORSHIP

The study used personal fund from the main author.

\section{ACKNOWLEDGEMENT}

We give our best gratitude to Krembangan and Pabean Cantikan community health centers, Surabaya, East Java, that have allow us to conduct the study.

\section{REFERENCE}

Alderman H, Headey DD (2017). How important is parental education for child nutrition? World Dev, 94: 448-464. doi: 10.1016/j.worlddev.2017.02-.007.

Corsi DJ, Mejía-Guevara I, Subramanian SV (2016). Risk factors for chronic under nutrition among children in India: Estimating relative importance, population attributable risk and fractions. Soc Sci Med, 157: 165-185. doi: 10.1016/j.socscimed.2015.11.014.

Crane RJ, Jones KDJ, Berkley JA (2015). Environmental enteric dysfunction: An overview. Food and Nutrition Bulletin, 36(1): S76-S87. doi: 10.11-77/1564826$5150361 \mathrm{~S} 113$.

Creanga AA, Gullo S, Kuhlmann AKS, Msiska TW, Galavotti C (2017). Is quality of care a key predictor of perinatal health care utilization and patient satisfaction in Malawi? BMC Pregnancy and Childbirth, 17(1): 1-13. doi: 10.1186/s12884017-1331-7.

Adriani M (2016). Peranan Gizi Dalam Siklus Kehidupan. Jakarta: Kencana Prenadamedia Group. 
Dessie ZB, Fentie M, Abebe Z, Ayele TA, Muchie KF (2019). Maternal characteristics and nutritional status among 6-59 months of children in Ethiopia: Further analysis of demographic and health survey. BMC Pediatrics, 19(1): 110. doi: 10.1186/s-12887-019-1459-x.

Eshete H, Abebe Y, Loha E, Gebru T, Tesheme $T$ (2017). Nutritional status and effect of maternal employment among children aged 6-59 months in Wolayta Sodo Town, Southern Ethio-pia: A Cross-sectional Study. Ethiop J Health Sci, 27(2): 155-162. doi: 10.-4314/ejhs.v27i2.8.

Istiany A, Rusilanti (2013). Gizi Terapan. Bandung: PT. Remaja Rosdakarya.

Khaing HT, Nomura S, Yoneoka D, Ueda P, Shibuya K (2019). Risk factors and regional variations of malnutrition among children under 5 in Myanmar: cross-sectional analyses at national and subnational levels. BMJ Open, 9(9): 18. doi: 10.1136/bmjopen-2019-030894. Khanal V, Sauer K, Karkee R, Zhao Y (2014). Factors associated with small size at birth in Nepal: Further analysis of Nepal Demographic and Health Survey 2011. BMC Pregnancy and Childbirth, 14(1). doi: 10.1186/1471-2393-14-32.

Kusuma IR, Salimo H, Sulaeman ES (2017). Path analysis on the effect of birthweight, maternal education, stimulation, exclusive breastfeeding, and nutritional status on motoric development in children aged 6-24 months in Banyumas District, Central Java. J Matern Child Health, 2(1): 64-75. https://doi.org/10.26911/thejmch.2017 .02.01.07.

Mahmudiono T, Nindya T, Andrias D, Megatsari H, Rosenkranz R (2018). Household food insecurity as a predictor of stunted children and overweight/obese mothers (SCOWT) in
Urban Indonesia. Nutrients, 10(5):1-16. doi: 10.3390/nu10050535.

Makoka D, Masibo PK (2015). Is there a threshold level of maternal education sufficient to reduce child undernutrition? Evidence from Malawi, Tanzania and Zimbabwe. BMC Pedia-trics, 15(1): 1-10. doi: 10.1186-/s1288-7-0150406-8.

Miller LC, Joshi N, Lohani M, Rogers B, Mahato S, Ghosh S, Webb P (2017). Women's education level amplifies the effects of a livelihoods-based intervention on household wealth, child diet, and child growth in rural Nepal. Int J Equity Health, 16(1): 1-17. doi: 10.1186/s129-39-017-0681-0.

Mutisya M, Kandala N, Ngware AMW, Kabiru CW (2015). Household food (in) security and nutritional status of urban poor children aged 6 to 23 months in Kenya Global health. BMC Public Health, 15(1): 1-10. doi: 10.11-86/s12889-015-2403-0.

Nazri C, Yamazaki C, Kameo S, Herawati DMD, Sekarwana N, Raksanagara A, Koyama H (2016). Factors influencing mother's participation in Posyandu for improving nutritional status of children under-five in Aceh Utara district, Aceh province, Indonesia. BMC Public Health, 16(1): 1-9. doi: 10.1186/s12889-016-2732-7.

Osguei NK, Mascie-Taylor CGN (2019). Association of nutritional status with socio-economic and demographic variables of under five year old children. MJIRI, 33(1): 165-174. doi: 10.341711/mjiri.33.28.

Pal A, Pari AK, Sinha A, Dhara PC (2017). Prevalence of under nutrition and associated factors: A cross-sectional study among rural adolescents in West Bengal, India. International Journal of Pediatrics and Adolescent Medicine, 
Aziza et al./ Contextual Effect of Integrated Heath Post on Nutritional Status

4(1): 9-18. doi: 10.1016/-j.ijpam.2016.08.009.

Pangestu ND, Joebagio H, Rahardjo SS (2017). The role of community health workers in maternal and child health surveillance to optimize maternal and child health in Pasu-ruan District, East Java. J Health Policy Manage, 2(2): 128-136. https://doi.org/10.26911/thejhpm.2017.02.02.04

Rah JH, Cronin AA, Badgaiyan B, Aguayo VM, Coates S, Ahmed S (2015). House hold sanitation and personal hygiene practices are associated with child stunting in rural India: A cross-sectional analysis of surveys. BMJ Open, 5(2): 111. doi: 10.1136/bmj-open-2014-005180.

Rahayu BZ, Budihastuti UR, Rahardjo SS (2019). Contextual effect of community health center on low birtweight in East Lombok, Nusa Tenggara Barat. J Matern Child Health, 4(3): 136-145. https://doi.org/10.26911/-thejmch.2019.04.03.01

Rahayu RM, Pamungkasari EP, Wekadigunawan CSP (2018). The biopsychosocial determinants of stunting and wasting in children aged 12-48 months. J Matern Child Health, 3(2): 105-118. https://doi.org/10.26911/-thejmch.2018.03.02.03

Renzaho A, Chitekwe S, Chen W, Rijal S, Dhakal T, Dahal P (2018). The synergetic effect of targeted resource transfers for families, child sensitive social protection programs, and capacity building for effective social protection on children's nutritional status in Nepal. Int J Environ Res public health, 15(5): 1-7. doi: 10.33-90/ijerph15050869.

Riyadi A (2016). Ilmu Kesehatan Masya- rakat. Yogyakarta: ANDI.

Rose ES, Blevins M, González-Calvo L, Ndatimana E, Green AF, Lopez M, Olupona $\mathrm{O}$, Vermund $\mathrm{SH}$, et al. (2015). Determinants of undernutrition among children aged 6 to 59 months in rural Zambézia Province, Mozambique: results of two population-based serial cross sectio-nal surveys. BMC Nutrition, 1(1): 1-20. doi: 10.1186/s40795015-0039-1 .

Tamimi MA, Jurnalis YD, Sulastri D (2016). Hubungan Pemberian ASI eksklusif dengan kejadian diare pada bayi di Wilayah Puskesmas Nanggalo Pa-dang. Jurnal Kesehatan Andalas, 5(1): 149153. Retrieved from http://jurnal.fk.unand.ac.id

Tofail F, Fernald LC, Das KK, Rahman M, Ahmed T, Jannat KK, Unicomb L, Arnold BF, et al. (2018). Effect of water quality, sanitation, hand washing, and nutritional interventions on child development in rural Bangladesh (WASH Benefits Bangladesh): a cluster-randomized controlled trial. Lancet Child Adolesc Health, 2(4): 255-268. doi: 10.1016/S2352-4642(18)30-031-2.

Vollmer S, Bommer C, Krishna A, Harttgen K, Subramanian S (2017). The association of parental education with childhood under nutrition in low and middle-income countries: Comparing the role of paternal and maternal education. Int J Epidemiol, 46(1): 312323. doi: 10.1093/ije/dyw133.

Wright M, Mendez MA, Alvarez DS, Adair, L (2016). Breastfeeding and protein intake influence body mass index from 2 months to 22 years in the Cebu longitudinal health and nutrition survey. J Nutr, 146(10): 2085-2092. doi: 10.3945/jn.116.232470. 